\title{
Rational, computer-aided design of multi-target ligands
}

\author{
J Achenbach*, E Proschak \\ From 6th German Conference on Chemoinformatics, GCC 2010 \\ Goslar, Germany. 7-9 November 2010
}

Over the past two decades the "one drug - one target one disease" concept became the prevalent paradigm in drug discovery. The main idea of this approach is the identification of a single protein target whose inhibition leads to a successful treatment of the examined disease. The predominant assumption is that highly selective ligands would avoid unwanted side effects caused by binding to secondary non-therapeutic targets.

In recent years the results of post-genomic and network biology showed that proteins rarely act in isolated systems but rather as a part of a highly connected network [1]. In addition this connectivity leads to more robust systems that cannot be interfered by the inhibition of a single target of that network and consequently might not lead to the desired therapeutic effect [2]. Furthermore studies prove that robust systems are rather affected by weak inhibitions of several parts than by a complete inhibition of a single selected element of that system [3].

Therefore there is an increasing interest in developing drugs that take effect on multiple targets simultaneously but is concurrently a great challenge for medicinal chemists. There has to be a sufficient activity on each target as well as an adequate pharmacokinetic profile [4]. Early design strategies tried to link the pharmacophors of known inhibitors, however these methods often lead to high molecular weight and low ligand efficacy.

We present a new rational approach based on a retrosynthetic combinatorial analysis procedure [5] on approved ligands of multiple targets. These RECAP fragments are used to design a large combinatorial library containing molecules featuring chemical properties of each ligand class. The molecules are further validated by

\footnotetext{
* Correspondence: Achenbach@pharmchem.uni-frankfurt.de Pharmaceutical Chemistry, Goethe University, 60438 Frankfurt am Main, Germany
}

machine learning models, like random forests and selforganizing maps, regarding their activity on the targets of interest.

Published: 19 April 2011

\section{References}

1. Jeong $H$, Mason SP, Barabási AL, Oltvai ZN: Lethality and centrality in protein networks. Nature 2001, 411:41-42

2. Kitano H: Towards a theory of biological robustness. Molecular Systems Biology 2007, 3:137.

3. Agoston V, Csermely P, Pongor S: Multiple weak hits confuse complex systems: a transcriptional regulatory network as an example. Phys $\operatorname{Rev} E$ 2005, 71:051909.

4. Morphy R, Rankovic Z: Designing multiple ligands - medicinal chemistry strategies and challenges. Curr Pharm Design 2009, 15:587-600.

5. Lewell $X Q$, Judd DB, Watson SP, Hann MM: RECAP - retrosynthetic combinatorial analysis procedure: a powerful new technique for identifying privileged molecular fragments with useful applications in combinatorial chemistry. J Chem Inf Comput Sci 1998, 18:511-522.

doi:10.1186/1758-2946-3-S1-P10

Cite this article as: Achenbach and Proschak: Rational, computer-aided design of multi-target ligands. Journal of Cheminformatics 2011 3(Suppl 1):P10.
Publish with ChemistryCentral and every scientist can read your work free of charge

"Open access provides opportunities to our colleagues in other parts of the globe, by allowing anyone to view the content free of charge."

W. Jeffery Hurst, The Hershey Company.

- available free of charge to the entire scientific community

- peer reviewed and published immediately upon acceptance

- cited in PubMed and archived on PubMed Central

- yours - you keep the copyright

Submit your manuscript here:

http://www.chemistrycentral.com/manuscript/

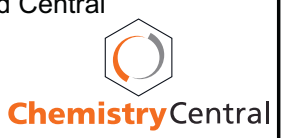

